\title{
Differential prevalence of depressive and narcissistic traits in competing and non-competing bodybuilders in relation to muscle dysmorphia levels
}

\author{
Zróżnicowanie występowania cech depresyjnych i narcystycznych wśród kulturystów \\ trenujących wyczynowo i amatorsko w odniesieniu do poziomu dysmorfii mięśniowej \\ 1 Department of Health Sciences, University of Florence, Florence, Italy \\ ${ }^{2}$ Department of Psychology, University of Turin, Turin, Italy \\ ${ }^{3}$ Department of Neurological and Sensorial Sciences, University of Siena, Siena, Italy \\ Correspondence: Matteo Angelo Fabris, Department of Psychology, University of Turin, Turin, Via Verdi 10, 10123 T0, Italy, e-mail: matteoangelo.fabris@unito.it
}

\begin{abstract}
Background: Muscle dysmorphia is considered a subtype of body dysmorphic disorder with a high prevalence in bodybuilders. Observational and experimental data suggest a differential prevalence for depressive and narcissistic-like traits between people involved in competing or non-competing bodybuilding activity. Methods: Here we assessed symptoms related to muscle dysmorphia (Muscle Dysmorphic Disorder Inventory, MDDI), depression (Back Depression Inventory, BDI), and narcissism (Narcissistic Personality Inventory, NPI) (among others dimensions) in 260 subjects representing non-training subjects (controls), competing and non-competing bodybuilders. Given the large variability within the sample, a data-driven classification approach allowed excluding outliers as well competing/non-competing subjects not showing any clinically significant features, thereby restricting the analysis to a core group of subjects $(n=178)$. Results: Results showed a significant difference in depression and narcissism levels between competing and non-competing bodybuilders (NPI, $F=34.186, p<0.01$; BDI, $F=10.298$, $p<0.05$ ), with higher level of narcissism detected in the former ones, while a slight depressive symptomatology has been identified in the latter ones. Post-hoc comparisons ( $p<0.05$ Bonferroni corrected) showed significant differences between competing/non-competing subjects and controls. Conclusions: Our results suggest a potential interaction between muscle dysmorphic symptoms, narcissism and depression, with a stronger association between narcissistic traits and the development of more severe muscle dysmorphic conditions in competing bodybuilders.
\end{abstract}

Keywords: muscle dysmorphia, narcissism, depression, bodybuilding

Streszczenie Wstęp: Dysmorfię mięśniową uznaje się za podtyp zaburzeń dysmorficznych ciała o wysokiej częstości występowania wśród osób uprawiających kulturystykę. Dane z badań obserwacyjnych i eksperymentalnych sugerują, iż osoby trenujące kulturystykę wyczynowo i amatorsko cechują się zróżnicowanym występowaniem cech depresyjnych i narcystycznych. Metoda: W niniejszym badaniu dokonano oceny objawów związanych z dysmorfią mięśniową (skala MDDI - Muscle Dysmorphic Disorder Inventory), depresją (Inwentarz Depresji Becka, Back Depression Inventory, BDI) i narcyzmem (Inwentarz Osobowości Narcystycznej, Narcissistic Personality Inventory, NPI) w grupie 260 osób, w tym osób nietrenujących (grupa kontrolna) oraz kulturystów trenujących wyczynowo i amatorsko. Biorąc pod uwagę dużą zmienność w obrębie grupy klasyfikacja na podstawie danych umożliwiła wykluczenie elementów odstających, jak również osób trenujących kulturystykę wyczynowo i amatorsko, które nie wykazywały żadnych istotnych klinicznie cech, co pozwoliło na ograniczenie analizy do grupy podstawowej $(n=178)$. Wyniki: W badaniu wykazano istotną różnicę w poziomie depresji i narcyzmu między kulturystami trenującymi wyczynowo a osobami uprawiającymi ten sport amatorsko (NPI, $F=34,186, p<0,01$; BDI, $F=10,298, p<0,05$ ), przy czym pierwsza grupa charakteryzowała się większym poziomem narcyzmu, natomiast druga grupa wykazywała nieznaczne objawy depresji. Porównania post-hoc ( $p<0,05$ po uwzględnieniu poprawki Bonferroniego) ujawniły istotne różnice między uczestnikami badania trenującymi wyczynowo/amatorsko a grupą kontrolną. Wnioski: Przedstawione wyniki sugerują istnienie potencjalnej interakcji między objawami dysmorfii mięśniowej, narcyzmem i depresją, przy czym silniejszą korelację stwierdzono między cechami narcystycznymi a rozwojem dysmorfii mięśniowej o większym nasileniu wśród kulturystów zawodowych. 


\section{INTRODUCTION}

$\mathrm{M}$ uscle dysmorphia (MD) is considered a particular subtype of body dysmorphic disorder (BDD) (Pope et al., 1997, 1993) which affects people obsessed by the idea of having a perfect muscular body. People with MD tend to see themselves as thinner than they actually are. To resolve this defect, they engage in exhausting exercise regimens, follow a strict high-protein diet and eat frequently, even if not hungry. This dietary habit could reach extreme levels, with subjects having up to 10 meals per day, eating up to 30 raw eggs. Moreover, if they deviate from their diet plan, they show increases in anxiety levels and engage in behaviours aimed to reduce their fat mass, such as fasting and compulsive exercise. In addition, the development of a special relationship with the mirror is not unusual, engaging in checking behaviours to reduce the anxiety caused by preoccupations of feeling small and inadequately muscular (Olivardia, 2001). Obsession with muscularity could become really overwhelming and time-consuming, as pointed out in a study (Olivardia et al., 2000) showing that $50 \%$ of a sample of 24 males with MD reported that they spent more than 3 hours per day thinking about their muscularity.

This syndrome is often associated with a concomitant abuse of drugs aimed at enhancing muscles, to the point that could cause medical problems (Murray et al., 2016; Pope and Katz, 1994; Rohman, 2009; Settanni et al., 2018). Androgenic anabolic steroids (AAS) are relatively common among male adults and teenagers with negative body image (Santarnecchi and Dèttore, 2012; Longobardi et al., 2017; Murray et al., 2016; Settanni et al., 2018). When used to enhance one's appearance (appearance-based motivation), AASs are often associated with greater incidence of eating disorders and MD-associated psychopathologies, as compared to performance-enhancing applications (Murray et al., 2016). Despite any dietary strategy and hours spent in the gym, their mirror still reflects an image of a skinny person, causing distress and reinforcing a vicious cycle of damaging behaviours. As a consequence of this perception bias, persons with MD experience marked discomfort and considerable distress when exposing their bodies (i.e. beaches, changing rooms, intimacy) without being able to avoid these situations (Olivardia et al., 2000). The uneasiness associated with the exposure of one's body to others could bring on severe avoidance behaviours. About $58 \%$ of MD subjects assessed by Olivardia et al. (2000) reported "moderate" or "severe" avoidance of activities, places, and people due to their perceived body defect. Thus, muscle dysmorphic subjects have a poor quality of life: social relationships become poorer and dreaded, and other aspects of normal life, such as work and hobbies, are neglected in favour of a compulsive attempt to increase muscular mass.

Pope and colleagues placed this syndrome under the BDD category. In DSM-5 (American Psychiatric Association, 2013), it is considered a specifier for diagnosing BDD, but in this nuance it is considered a subtype of BDD rather than an independent disorder by itself. DSM- 5 classifies BDD together with obsessive-compulsive disorder (OCD) in a new chapter on "obsessive-compulsive and related disorders," at last and rightly removing it from somatoform disorders. A conceptualisation of $\mathrm{MD}$ as an obsessive-compulsive spectrum disorder is possible by virtue of the fact that this disease is usually associated with obsessive compulsive features, as shown by the entire BDD category (Chandler et al., 2009; Chung, 2001; Longobardi et al., 2017; Maida and Armstrong, 2005). Moreover, as a study by Maida and Armstrong (2005) demonstrated, MD symptomatology was best predicted by a combination of obsessive compulsive features, body dissatisfaction, and hostility, indicating that MD has a strong relationship with the spectrum of conditions related to OCD. $\mathrm{BDD}$ and MD share the core symptomatic features, such as excessive attention to physical appearance and repetitive and time-consuming behaviours; some differences are to be highlighted as well. First of all, patients with MD show greater psychosocial impairment, poorer quality of life, and an enhanced risk of suicide than patients with BDD (Pope et al., 2005). Individuals with $\mathrm{MD}$ also put more insight into appearance than those with BDD (Olivardia et al., 2000); furthermore, subjects with MD tend to show higher comorbidity with addiction disorders (Pope et al., 2005). Lastly, they are significantly more likely to lift excessive weights ( $71 \%$ versus $12 \%$ ), follow a diet ( $71 \%$ versus $27 \%)$, and exercise immoderately ( $64 \%$ versus $10 \%)$, placing $\mathrm{MD}$ in the same category as eating disorders (Phillips et al., 2010; Lavender et al., 2017; Murray et al., 2010). Consequently, Murray et al. (2010) proposed to assign $\mathrm{MD}$ to the eating disorder spectrum due to similarities that pool these disorders, such as symptom nucleus, epidemiology (Olivardia et al., 2000), aetiological characteristics and treatment response (Grieve, 2007). Olivardia et al. (2000) pointed out also that men with MD obtained similar Eating Disorder Inventory (EDI) results as those with eating disorders (Garner et al., 1983), especially in "perfectionist traits," "maturity fears," "feelings of ineffectiveness," and "drive for thinness" subscales. Moreover, MD patients and those with eating disorders share sustained and elevated concerns with body image, diet, and exercise (Davis and Scott-Robertson, 2000; Mangweth et al., 2001; Murray et al., 2012). Besides, these similarities were found also among women with MD and those with eating disorders (Goldfield, 2009; Walberg and Johnston, 1991). Although similar, these disorders differ for the lack of pathological "drive for thinness" that characterises anorexia nervosa, which is replaced by the need to appear extremely lean and muscular. Therefore, even if $29 \%$ of men with MD had previously suffered from eating disorders (Olivardia et al., 2000) history of MD predisposing to developing eating disorders it is not possible yet to understand the existent relationship between these psychopathologies, whether they are part of the same phenomenological group or whether they set up as mutual risk factors.

In conclusion, notwithstanding the DSM-5 position, MD seems a borderline condition that shares characteristics with various disorders, such as $\mathrm{OCD}, \mathrm{BDD}$ and eating disorders, but 
has some peculiar and specific aspects, which can differentiate it from the other ones. We need further studies and theoretical elaborations that could offer clearer views on this condition, as well as its triggering and maintaining mechanisms.

Body dysmorphic concerns and eating disorders are the conditions most strictly linked to MD (Badenes-Ribera et al., 2019; Fabris et al., 2020a, 2020b) and we know that grooming/control of body shape and eating are powerful control and coping strategies. Consequently, pinpointing the emotional processes would probably contribute to our knowledge of MD. To this end, we refer to relatively recent proposals by Gilbert and Miles (2002), Goss and Gilbert (2002) and Thompson and Kent (2001), according to which a "shamed self," as a consequence of perceiving body as unattractive and undesirable, could cause psychological distress and disorders. "Shame" and its opposite, "pride," are, according to this view, central emotions in body and eating disorders; Goss and Gilbert (2002) propose an interesting double model for eating disorders, founded on alternating shame and pride.

From this perspective, we could consider MD as an excessive focalisation on one's own body in an effort to cope with shame, a compensatory maintenance of self-esteem heavily dependent on body image - with rigid and exigent standards, derived from social pressure and peculiar life events. According to the model proposed by Goss and Gilbert (2002), pride is a fundamental emotion in subjects with disordered eating behaviours and a negative perception of their body image. These individuals can experience pride in their ability to control diet, body weight, and shape, and to resist desires or impulses to eat, while shame is associated with failure to succeed in these endeavours. This can also apply to people with muscle dysmorphic symptoms when they follow their training plan and their diet regime in order to increase their muscle mass.

If the coping effort is successful (standards are achieved), the subject experiences pride and a sense of superiority that are strictly linked to narcissism, a core feature of eating disorders (Bruch, 1973; Lehoux et al., 2000; Steinberg and Shaw, 1997), which we hypothesise to be also central in MD. Evidence suggests a link between narcissistic traits and competition in different disciplines (Elman and McKelvie, 2003; Gat and McWhirter, 1998; Porcerelli and Sandler, 1995; Rubinstein, 2003), and higher levels of narcissism predict more frequent physical exercise (Miller and Mesagno, 2014). Individuals with high levels of narcissism can invest in physical appearance and physical exercise in an attempt to strengthen or enhance their sense of self-worth (Gordon and Dombeck, 2010; Miller and Mesagno, 2014). In this direction, some evidence suggests a possible relationship between narcissism and drive for muscularity (Littrell et al., 2020); however, the literature on the relationship between narcissism and muscle dysmorphic symptoms is scarce and inconclusive (Kuennen and Waldron, 2007; Littrell et al., 2020), and calls for further investigation.

On the contrary, if standards are not or only partially met, shame prevails and persists, with serious consequences on the mood, since the role of shame (also body-related) as a mediator in depression is well-known (Ding et al., 2012; Evans, 2011; Grabe et al., 2007; Matos et al., 2013). Consequently, in MD we could assist to alternating depressive and narcissistic states, according to prevailing shame or pride, as a result of success or failure in attaining the high standard for body image.

Bodybuilders (BBs) are at a greater risk of muscle dysmorphic symptoms (Santarnecchi and Dèttore, 2012; Fabris et al., 2018; Hildebrandt et al., 2006; Longobardi et al., 2017; Rubio-Aparicio et al., 2020), probably due to their focus on muscle development. On average, BBs score significantly higher in scales/questionnaires addressing MD symptoms as compared to non-BB resistance trainers (Mitchell et al., 2017). Researchers found higher levels of body dissatisfaction, social physique anxiety, disordered eating behaviours and unhealthy behaviours, such as excessive exercise and anabolic steroid intake, in this population (Davis and ScottRobertson, 2000; Longobardi et al., 2017; Schwerin et al., 1996). In Italy, almost $25 \%$ of male BBs have been shown to be at risk of developing $\mathrm{MD}$, with greater risk for younger athletes (Fabris et al., 2018; Longobardi et al., 2017).

Since literature shows that there is a high prevalence of MD in BBs (around 10-15\%; cfr. Hildebrandt et al., 2006; Pope et al., 1997) and that its severity increases with increasing competitiveness of these athletes (e.g. Santarnecchi and Dèttore, 2012; Skemp et al., 2013), we could test our model by comparing three different groups; two groups of competing (C-BBs) and non-competing BBs (NC-BBs) and one composed of non-training subjects (CCs). The two BB groups were chosen for significant levels of MD. According to our model, we could elaborate the following hypotheses:

1. C-BBs show the highest levels of MD compared with $\mathrm{NC}-\mathrm{BBs}$ and CCs since this group is the one working harder with the aim of ameliorating body image according to strict criteria. Competition probably encourages them to achieve higher levels of hypertrophy and perfection. This could increase concern for musculature and stimulate muscle-related behaviours.

2. C-BBs show the highest levels of trait narcissism compared with NC-BBs and CCs, as a result of their probable greater success in attaining the desired body forms.

3. NC-BBs show the highest levels of depression compared with C-BBs, as a consequence of their inferior success in gaining a perfect and muscular body.

4. In any case, narcissism and depression act as mediating factors in sustaining and increasing $\mathrm{MD}$, especially in $\mathrm{C}$-BBs, since this is the group with higher levels of attention and concerns about body image.

\section{METHODS}

\section{Participants}

To achieve our goals, we recruited a sample of male BBs (both competitive and non-competitive) and a sample 
of non-training men. BBs were recruited through fliers, online posts, bodybuilding conferences and fitness centres. Non-training men were recruited among the University of Siena and University of Florence community, through fliers and online posting. The participants were all healthy volunteers with no history of neurological and/or psychiatric conditions, and did not receive any reimbursement to participate in the study. Our overall initial sample included 260 male participants divided into three subsamples: 71 male C-BBs ( $M$ age $=33$ years; $S D$ age $=4$ years; age range $22-41$ years; body mass index, $\mathrm{BMI}=28.12$ ); 103 NC-BBs $(M$ age $=33$ years; $S D$ age $=9$ years; age range $22-36$ years; $\mathrm{BMI}=26.43) ; 86$ CCs $(M$ age $=31$ years; $S D$ age $=7$ years; age range $22-37$ years; $\mathrm{BMI}=21.19$ ) The participants completed an anonymous survey including socio-demographic data and underwent a series of tests aimed at evaluating both MDD symptomatology, and dimensions of narcissism and depression. BMI data was also collected through a direct height/weight measurement, following the canonical formula weight/(height) ${ }^{2}$. Starting from this sample, we then identified outliers (i.e. participants with depression and narcissism who scored more than $2 S D$ above the group mean) and those subjects showing a mixed pattern of depression/narcissism symptomatology, which could have introduced noise in the subsequent analysis. The results of this procedure are shown in Fig. 1A and B, with subjects reporting predominant depressive and narcissistic symptomatology clearly loading on two separate clusters (Fig. 1A), which also matches a neat differential representation, in terms of frequency, within the three subsamples (Fig. 1B). Eventually, our final sample included 178 participants: $40 \mathrm{C}$-BBs $(M$ age $=32$ years; $S D$ age $=3$ years; age range 23-39 years; $\mathrm{BMI}=28.45)$; 70 NC-BBs $(M$ age $=33$ years; $S D$ age $=8$ years; age range $21-36 ; \mathrm{BMI}=25.54) ; 68 \mathrm{CCs}$

\begin{tabular}{|l|c|c|}
\hline & $\boldsymbol{n}$ & $\%$ \\
\hline C-BB & 40 & 22.47 \\
\hline NC-BB & 70 & 39.33 \\
\hline CC & 68 & 38.20 \\
\hline Total & 178 & 100.00 \\
\hline
\end{tabular}

Tab. 1. Number and \% of our final three groups of subjects

( $M$ age $=30 ; S D$ age $=4$ years; age range $23-36$ years; $\mathrm{BMI}=22.32)$ (see Tab. 1$)$.

\section{Instruments}

\section{Muscle Dysmorphic Disorder Inventory (MDDI) (Santarnecchi and Dèttore, 2012)}

The Muscle Dysmorphia Disorder Inventory (MDDI) is a measure of muscle dysmorphia derived from the Schlundt Muscle Dysmorphia Inventory (MDI) (unpublished manuscript) that originally consisted of 16 self-report items based on MD research criteria. Hildebrandt et al. (2004) revised the original MDI for the purpose of integrating the instrument with questions about the functional impairment characteristic of MD. The final version of MDDI items includes seven questions assessing three diagnostic factors associated with MD: desire for size, appearance anxiety/avoidance, and functional impairment. Participants rate all questions on a 5-point Likert-type scale from "never" (" 1 ”) to "always" ("5").

The factorial analysis conducted by Hildebrandt et al. (2004) revealed a consistent three-factor structure, regarding cognitions, emotions, and behaviours related to body image. The first subscale, Desire For Size (DFS), consists of questions concerning thoughts of being smaller, less muscular, and weaker than desired, or a wish to increase size and strength.
A

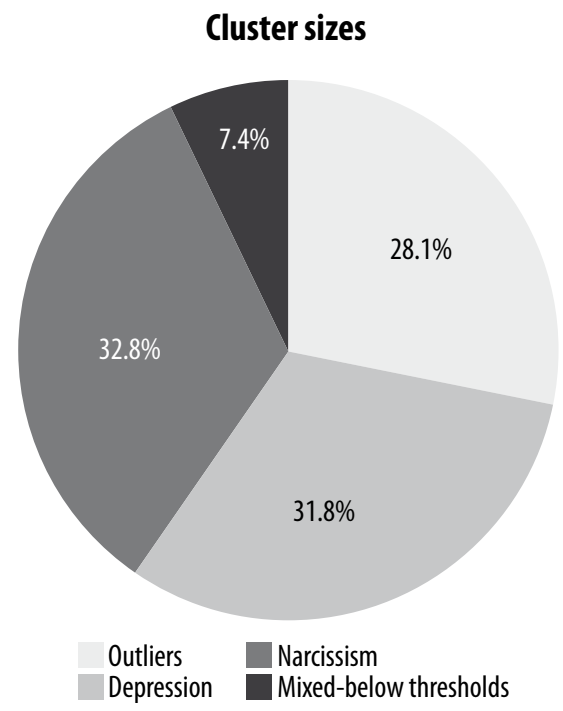

B

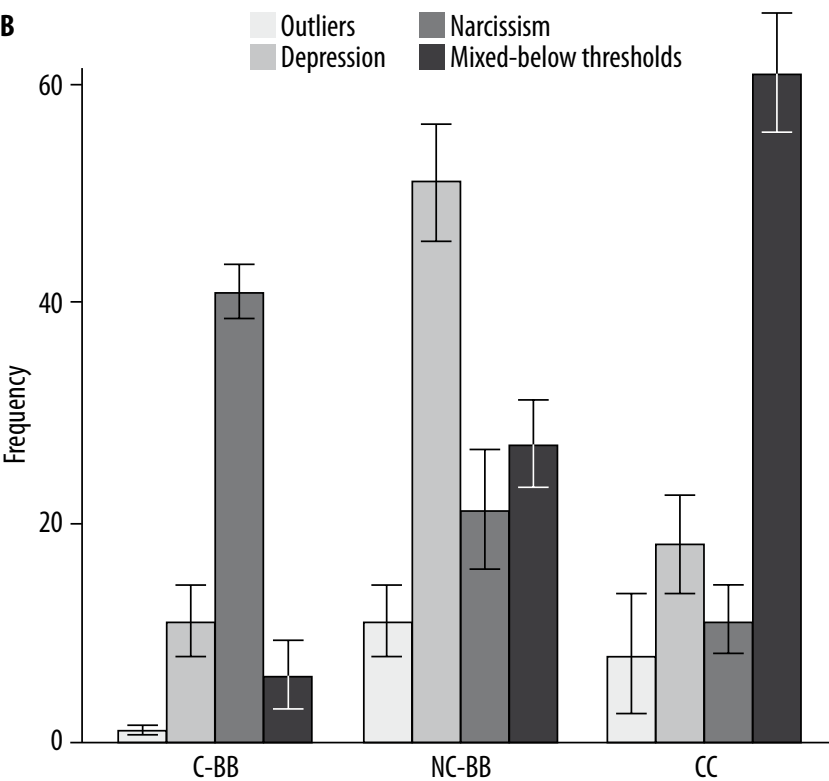

Fig. 1. Distribution of cluster sizes in BB according prevailing depression or narcissism, with outliers and mixed-below thresholds characteristics (A) and specification of the distribution of these characteristics in the three groups: $C-B B, N C-B B$ and $C C$ 
The thinking style represented by this subscale is consistent with the preoccupation about inadequate size in MD as described by Pope et al. (1997). The second factor, Appearance Intolerance (AI), explores negative beliefs about one's own body and the resulting appearance anxiety or body exposure avoidance. The negative cognitions and behavioural manifestations of core negative beliefs about one's own body are consistent with MD features, such as wearing baggy clothes to the beach or a belief that one's body is unattractive and distasteful. Finally, the Functional Impairment (FI) factor consists of questions about behaviours related to maintaining exercise routines, the interference of negative emotions when deviating from exercise routines, or avoidance of social situations due to negative feelings and preoccupation with one's own body.

\section{Body Dysmorphic Disorder - Yale-Brown Obsessive Compulsive Scale (BDD-Y-BOCS)}

BDD-Y-BOCS is a modified version of Yale-Brown Obsessive Compulsive Scale (Y-BOCS) (Phillips et al., 1997). It is a semi-structured clinical scale used to evaluate the severity of BDD symptomatology. BDD-Y-BOCS showed excellent inter-rater test-retest reliability (intraclass correlation coefficient, ICC 0.99 and 0.88), internal consistency (Cronbach's 0.80), and good convergent and discriminant validity. For this study, we used an Italian version of BDD-Y-BOCS, which has not been published yet, with usual procedures of translation/back-translation.

\section{Beck Depression Inventory-II (BDI-II)}

The Beck Depression Inventory-II (BDI-II) (Beck et al., 1996) was also used as a measure of treatment outcome. It is a 21-item self-report inventory to rate the severity of depressive symptoms. Items are rated from 0 to 3 and the total score ranges from 0 to 63 . It is a well-established measure and its psychometric properties are excellent (Dozois et al., 1998). For the Italian version (BDI-II, Italian version; Ghisi et al., 2006) internal consistency was excellent (Cronbach's $\alpha=0.92$ ) for the clinical sample and for the student sample (Cronbach's $\alpha=0.93$ ).

\section{Narcissistic Personality Inventory (NPI)}

The Narcissistic Personality Inventory (NPI) (Raskin and Terry, 1988; Raskin and Hall, 1979) is a self-administered instrument for the evaluation of narcissism also in non-clinical populations; it is based upon behavioural criteria for narcissistic personality included in DSM-III (American Psychiatric

\begin{tabular}{|c|c|c|c|c|c|c|}
\hline & & $n$ & $M$ & SD & Min & Max \\
\hline \multirow{4}{*}{ Age } & C-BB & 40 & 30.45 & 3.922 & 23 & 41 \\
\hline & NC-BB & 70 & 31.31 & 3.809 & 23 & 38 \\
\hline & $\mathrm{CC}$ & 68 & 30.56 & 4.820 & 21 & 39 \\
\hline & Total & 178 & 30.83 & 4.242 & 21 & 41 \\
\hline \multirow{4}{*}{ Body mass index } & C-BB & 39 & 28.2325 & 5.14682 & 3.40 & 34.60 \\
\hline & NC-BB & 69 & 24.7518 & 2.78714 & 19.82 & 34.34 \\
\hline & $\mathrm{CC}$ & 68 & 24.8239 & 2.63366 & 19.47 & 32.41 \\
\hline & Total & 176 & 25.5509 & 3.67230 & 3.40 & 34.60 \\
\hline \multirow{4}{*}{ Length of training [years] } & C-BB & 40 & 12.48 & 7.723 & 2 & 30 \\
\hline & NC-BB & 68 & 8.18 & 7.159 & 1 & 25 \\
\hline & $\mathrm{CC}$ & 68 & 1.41 & 5.100 & 0 & 24 \\
\hline & Total & 176 & 6.54 & 7.886 & 0 & 30 \\
\hline \multirow{4}{*}{ Age at training onset } & C-BB & 40 & 18.75 & 4.760 & 6 & 34 \\
\hline & NC-BB & 69 & 21.62 & 9.420 & 0 & 50 \\
\hline & $\mathrm{CC}$ & 68 & 0.47 & 1.888 & 0 & 12 \\
\hline & Total & 177 & 12.85 & 11.746 & 0 & 50 \\
\hline \multirow{4}{*}{$\begin{array}{l}\text { Number of trainings sessions } \\
\text { per week }\end{array}$} & C-BB & 40 & 4.68 & 2.314 & 2 & 18 \\
\hline & NC-BB & 70 & 3.19 & 1.300 & 0 & 6 \\
\hline & $\mathrm{CC}$ & 68 & 0.49 & 1.966 & 0 & 13 \\
\hline & Total & 178 & 2.49 & 2.473 & 0 & 18 \\
\hline \multirow{4}{*}{ Fat mass index } & C-BB & 40 & 29.00 & 16.916 & 10 & 70 \\
\hline & NC-BB & 70 & 42.00 & 19.752 & 10 & 80 \\
\hline & $\mathrm{CC}$ & 68 & 48.18 & 23.215 & 6 & 90 \\
\hline & Total & 178 & 41.44 & 21.718 & 6 & 90 \\
\hline \multirow{4}{*}{ Muscle mass index } & C-BB & 40 & 61.75 & 13.376 & 30 & 90 \\
\hline & NC-BB & 70 & 45.71 & 16.381 & 10 & 90 \\
\hline & $\mathrm{CC}$ & 68 & 34.71 & 16.251 & 10 & 70 \\
\hline & Total & 178 & 45.11 & 18.663 & 10 & 90 \\
\hline
\end{tabular}

Tab. 2. Descriptive statistics of age, body mass index, length of training, age at training onset, number of training sessions per week, fat mass index, muscle mass index of the $C-B B, N C-B B$ and $C C$ 


\begin{tabular}{|c|c|c|c|c|c|c|}
\hline & C-BB $(n=40)$ & NC-BB $(n=70)$ & $\mathrm{CC}(n=68)$ & & & \\
\hline & $M(S D)$ & $M(S D)$ & $M(S D)$ & $\boldsymbol{F}$ & Partial $\eta^{2}$ & LSD post hoc comparisons* \\
\hline Body mass index & $28.23(5.14)$ & $24.75(2.78)$ & $24.82(2.63)$ & 15.59 & 0.15 & $C-B B>N C-B B=C C$ \\
\hline Fat mass index & $29.00(16.91)$ & $42.00(19.75)$ & $48.18(23.21)$ & 10.96 & 0.11 & $C C=N C-B B>C-B B$ \\
\hline Muscle mass index & $61.75(13.37)$ & $45.71(16.38)$ & $34.71(16.25)$ & 37.40 & 0.29 & $\mathrm{C}-\mathrm{BB}>\mathrm{NC}-\mathrm{BB}>\mathrm{CC}$ \\
\hline
\end{tabular}

Tab. 3. Mean scores (standard deviations) of the C-BB, NC-BB and CC on the body, fat and muscle mass indices and between-group difference tests of significance

\begin{tabular}{|c|c|c|c|c|c|c|}
\hline & C-BB $(n=40)$ & NC-BB $(n=70)$ & $C C(n=68)$ & & & \\
\hline & $M(S D)$ & $M(S D)$ & $M(S D)$ & $\boldsymbol{F}$ & Partial $\eta^{2}$ & LSD post hoc comparisons* \\
\hline BDD-Y-BOCS & $7.80(5.44)$ & $5.24(5.37)$ & $3.44(4.11)$ & 9.80 & 0.10 & $C-B B>N C-B B>C C$ \\
\hline
\end{tabular}

Tab. 4. Means (standard deviations) of $C-B B, N C-B B$ and CC for the BDD-Y-BOCS, and between-group differences significance test

Association, 1980). In the study of Raskin and Terry (1988), the NPI acquired its actual form of 40 items, but its original 7-subscale structure was not confirmed: internal consistency coefficients (Guttman's lambda 3) showed acceptable values only for the total score of NPI (0.83) and for the Authority subscale (0.73). Similar results were reported by del Rosario and White (2005). The Italian translation and validation of NPI (Fossati et al., 2008) showed that NPI has internal consistency in different samples for age, sex and clinical condition: Cronbach's alphas for total score are superimposable on values reported by del Rosario and White (2005) $(0.80 / 0.82)$ and by del Rosario and White (2005) (0.81) for the total score of the 40 item NPI.

The results of the factorial analyses of the Italian version of NPI confirm the perplexities on the multifactorial structure of the instrument, similarly to the results showed by Raskin and Terry (1988) and del Rosario and White (2005). All in all, the analyses of the correlation matrices suggest the fundamental unidimensionality of the scale as such it was considered in our study.

\section{Data analysis}

Random-effect ANOVAs with LSD multiple post-hoc comparisons were conducted to test for between-group differences in the BDI-II, NPI scores.

Univariate general linear models were conducted to examine main effects of NPI or BDI-II scores and groups, and to test for interaction effects between NPI or BDI-II scores and groups on MDDI scores, which were entered as dependent variables.

Between-group effect sizes were estimated using the partial eta squared index, as recommended by Olejnik and Algina (2003). According to Cohen's (1988) recommendations, effect sizes (ES) of 0.01, 0.06, 0.14 were interpreted as small, medium, and large, respectively.

\section{RESULTS}

\section{Descriptive statistics}

Tab. 2 summarises the main descriptive characteristics of our three groups of subjects, including anthropometric data.

Tab. 3 shows the between-groups differences and their significance for BMI. This index allows good differentiation of $\mathrm{C}-\mathrm{BB}$ from the other two groups and goes in the expected direction.

\section{Hypothesis 1}

A statistically significant between-group difference in BDD-Y-BOCS scores was found between the three groups $\left[F_{(2,175}=9.80, p=0.0001\right]$. The $\mathrm{C}-\mathrm{BB}$ group scored significantly higher compared to both the NC-BB and the CC groups. The NC-BB group scored significantly higher compared to the CC group (see Tab. 4).

\begin{tabular}{|c|c|c|c|c|c|c|}
\hline & C-BB $(n=40)$ & NC-BB $(n=70)$ & $\mathrm{CC}(n=68)$ & & & \\
\hline & $M(S D)$ & $M(S D)$ & $M(S D)$ & $F$ & Partial $\eta^{2}$ & LSD post hoc comparisons* \\
\hline MDDI total & $29.65(9.21)$ & $26.84(8.79)$ & $17.91(84.46)$ & 38.24 & 0.30 & $C-B B=N C-B B>C C$ \\
\hline MDDI Drive for Size & $13.38(5.03)$ & $11.37(4.29)$ & $7.27(2.90)$ & 35.51 & 0.27 & $\mathrm{C}-\mathrm{BB}>\mathrm{NC}-\mathrm{BB}>\mathrm{CC}$ \\
\hline $\begin{array}{l}\text { MDDI Appearance } \\
\text { Intolerance }\end{array}$ & $6.08(2.6)$ & $7.05(3.25)$ & $5.95(2.20)$ & 3.39 & 0.03 & $N C-B B>C C, N C-B B=C-B B, C-B B=C C$ \\
\hline $\begin{array}{l}\text { MDDI Functional } \\
\text { Impairment }\end{array}$ & $10.20(3.87)$ & $8.75(5.13)$ & $4.87(1.82)$ & 28.98 & 0.24 & $\mathrm{C}-\mathrm{BB}>\mathrm{CC}, \mathrm{C}-\mathrm{BB}=\mathrm{NC}-\mathrm{BB}, \mathrm{NC}-\mathrm{BB}>\mathrm{CC}$ \\
\hline
\end{tabular}

Tab. 5. Means (standard deviations) of C-BB, NC-BB and CC for the MDDI total and subscales, and between-group differences significance test 


\begin{tabular}{|c|c|c|c|c|c|c|}
\hline & C-BB $(n=40)$ & NC-BB $(n=70)$ & $\mathrm{CC}(n=68)$ & & & \\
\hline & $M(S D)$ & $M(S D)$ & $M(S D)$ & $F$ & Partial $\eta^{2}$ & LSD post hoc comparisons* \\
\hline BDI-II & $7.18(4.40)$ & $17.80(7.97)$ & $7.91(10.04)$ & 32.34 & 0.27 & $N C-B B>C-B B=C C$ \\
\hline NPI & $21.58(6.84)$ & $8.90(8.74)$ & $7.18(9.81)$ & 37.27 & 0.30 & $C-B B>N C-B B=C C$ \\
\hline
\end{tabular}

Tab. 6. Means (standard deviations) of C-BB, NC-BB and CC on the BDI-II and NPI, and between-group differences significance test

A statistically significant between-group difference in the total MDDI score was found between the three groups $\left[F_{(2,175)}=38.24, p=0.0001\right]$. Both the C-BB and the NC-BB groups scored significantly higher compared to the CC group (see Tab. 5).

Although no significant difference was found between the $\mathrm{C}-\mathrm{BB}$ and the NC-BB groups, the C-BB group had higher scores than the NC-BB group at a trend level (Mean Difference $=2.80, p=0.06$ ).

A statistically significant between-group difference in the MDDI Drive for Size subscale scores was found between the three groups $\left[F_{(2,175)}=33.51, p=0.0001\right]$. The $\mathrm{C}$-BB group scored significantly higher than the NC-BB and the CC groups. The NC-BB group scored significantly higher than the CC group.

A statistically significant between-group difference in the MDDI Appearance Intolerance subscale scores was found between the three groups $\left[F_{(2,175)}=3.39, p=0.036\right]$. The NC-BB scored significantly higher than the CC group. No significant difference emerged between the $\mathrm{C}-\mathrm{BB}$ and the $\mathrm{CC}$ group. Although no significant difference was found between the $\mathrm{C}-\mathrm{BB}$ and the NC-BB groups, the NC-BB group had higher scores than the $\mathrm{C}$ - $\mathrm{BB}$ group at a trend level (Mean Difference $=-0.92, p=0.06$ ).

A statistically significant between-group difference in the MDDI Functional Impairment subscale scores was found between the three groups $\left[F_{(2,175)}=28.98, p=0.0001\right]$. The C-BB group scored significantly higher than the CC group. The NC-BB group scored significantly higher than the CC group. Despite no significant difference between the $\mathrm{C}-\mathrm{BB}$ and the NC-BB groups, the $\mathrm{C}-\mathrm{BB}$ group had higher scores than the NC-BB group at a trend level (Mean Difference $=1.44, p=0.06$ ).

\section{Hypotheses 2-3}

A statistically significant difference in the BDI-II scores was found between $\mathrm{C}-\mathrm{BB}, \mathrm{NC}-\mathrm{BB}$, and $\mathrm{CC}$ groups $\left[F_{(2,175)}=32.34, p=0.0001\right]$. The NC-BB group scored significantly higher in BDI-II compared to both the C-BB and $\mathrm{CC}$ groups. No significant difference emerged between the C-BB and the CC groups (see Tab. 6).

A statistically significant difference in the NPI scores was found between the three groups $\left[F_{(2,175)}=32.34\right.$, $p=0.0001]$. The $\mathrm{C}-\mathrm{BB}$ group had significantly higher scores compared to both the NC-BB and CC groups. No significant difference emerged between the NC-BB and

\begin{tabular}{|l|c|c|c|c|}
\hline & $\boldsymbol{F}$ & $\boldsymbol{d f}$ & $\boldsymbol{p}$-value & Partial $\boldsymbol{\eta}^{2}$ \\
\hline NPI scores main effect & $19.95^{*}$ & 1,172 & 0.0001 & 0.10 \\
\hline Group main effect & $9.63^{*}$ & 2,172 & 0.0001 & 0.10 \\
\hline $\begin{array}{l}\text { Group per NPI interaction } \\
\text { effect }\end{array}$ & $4.09^{*}$ & 2,172 & 0.0180 & 0.05 \\
\hline $\begin{array}{l}\text { * Significant at } p \text {-value }<0.05 . \\
\text { df - degrees of freedom. }\end{array}$ & & & \\
\hline
\end{tabular}

Tab. 7. Statistics of main effects of group and NPI scores and interaction effects between NPI and group on MDDI scores

\begin{tabular}{|c|c|c|c|c|}
\hline & $\boldsymbol{F}$ & $d f$ & $p$-value & Partial $\eta^{2}$ \\
\hline BDI-II scores main effect & $19.17^{*}$ & 1,172 & 0.0001 & 0.100 \\
\hline Group main effect & $4.95^{*}$ & 2,172 & 0.0080 & 0.054 \\
\hline $\begin{array}{l}\text { Group per BDI-II } \\
\text { interaction effect }\end{array}$ & $3.70^{*}$ & 2,172 & 0.0270 & 0.041 \\
\hline
\end{tabular}

Tab. 8. Statistics of main effects of group and BDI-II scores and interaction effects between BDI-II and group on MDDI scores

\section{Hypothesis 4}

Main effects on the MDDI scores emerged for group $\left(F_{(2,172)}=9.63, p=0.0001\right.$, partial $\left.\eta^{2}=0.10\right)$ and for NPI scores $\left(F_{(1,172)}=19.95, p=0.0001\right.$, partial $\left.\eta^{2}=0.10\right)$. An interaction effect was found between NPI scores and group in the MDDI scores $\left(F_{(2,172)}=4.09, p=0.0180\right.$, partial $\left.\eta^{2}=0.05\right)$. Specifically, C-BB participants with higher NPI scores had significantly higher MDDI scores $(\beta=0.53$, $t=2.78, \mathrm{p}=0.006)($ see Tab. 7).

Main effects on the MDDI scores emerged for group $\left(F_{(2,172)}=4.95, p=0.00801\right.$, partial $\left.\eta^{2}=0.054\right)$ and for the BDI-II scores $\left(F_{(1,172)}=19.17, p=0.0001\right.$, partial $\left.\eta^{2}=0.10\right)$. An interaction effect was found between the BDI-II scores and group in MDDI scores $\left(F_{(2,172)}=3.70, p=0.0270\right.$, partial $\left.\eta^{2}=0.041\right)$. Specifically, C-BB participants with higher BDI-II scores had significantly higher MDDI scores $(\beta=0.75$, $t=2.70, p=0.008)$ (see Tab. 8).

\section{DISCUSSION}

The central aim of our study was to evaluate if narcissism and depression could differentiate professional and nonprofessional BBs with high levels of MD from non-training subjects, according to an aetiological model that views depressive and narcissistic states as strictly linked to MD. Our hypotheses were in most part confirmed: 
(i) C-BBs had the highest levels of BDD traits compared with NC-BBs and CCs. Also, they had the highest levels of $\mathrm{MD}$, even if the $\mathrm{C}-\mathrm{BB}$ group reported higher scores than the NC-BB group only at a trend level. This fits with recent data on the prevalence of MD among Italian BBs (Fabris et al., 2018; Longobardi et al., 2017).

(ii) C-BBs had the highest levels of trait narcissism. Even though previous studies have shown high level of narcissism in BBs (Carroll, 1989; Porcerelli and Sandler, 1995; Rubinstein, 2003), it is still unclear whether narcissistic traits constitute a cause or a consequence of bodybuilding practice. Our data do not allow us to draw definitive conclusions on this matter; however, they provide new insight about a potential difference between competitive and non-competitive BBs, suggesting an interaction between competitiveness and narcissism already reported for other disciplines (Elman and McKelvie, 2003; Gat and McWhirter, 1998). Moreover, our data suggest that perfectionism and narcissism are precursors of exercise addiction (Miller and Mesagno, 2014). The association between MD and narcissistic traits has not been extensively investigated. Even though narcissism and MD-related symptoms are usually documented in individuals with low self-esteem focused on increasing their muscle size, Kuennen and Waldron (2007) have previously reported a null association between the two dimensions. However, the authors reported a correlation between narcissism and perfectionism, the latter being often associated with MD symptoms. Moreover, a recent study by Littrell (2015) has shown, by parcellating narcissism dimension into subdomains, how a correlation between MD and "vulnerable narcissism" becomes relevant. Some authors suggest considering two subtypes of narcissism: grandiose and vulnerable. Grandiose narcissism, a core feature of narcissistic personality disorders (American Psychiatric Association, 2013), is characterised by a profound need for admiration, grandiose thought and behaviours, lack of empathy, an apparent security in social relations, and an intolerance of criticism and a tendency to devalue others (Littrell et al., 2020; Pincus and Lukowitsky, 2010). Vulnerable narcissism, on the other hand, is characterised by a poor self-image, anxiety in social relationships, hypersensitivity to the judgment and opinions of others. These subjects tend to respond to criticism by withdrawing, avoiding, and experiencing pervasive feelings of shame (Dickinson and Pincus, 2003; Littrell, 2015; Littrell et al., 2020). Some data suggest that vulnerable narcissism is more related to the development of body dysmorphic concerns and disordered eating behaviours (Back et al., 2010; Gordon and Dombeck, 2010; Littrell et al., 2020). (iii) Our data originally show that NC-BBs report the highest levels of depression. Boyda and Shevlin (2011) have previously reported significant levels of depression in a sample of BBs, also showing how such symptoms were more present in individuals who were victims of episodes of bullyism. Such experiences during early adult life might have significantly impact the likelihood of developing depression and MD as well as decrease the will to take part in any competitive activity and corresponding over-exposure. Additionally, it might be that NC-BBs systematically avoid competitive events in an attempt to avoid exposure and potential negative feedback, thereby increasing body dissatisfaction and depressive symptoms.

Various studies have investigated the association between $\mathrm{MD}$ and depression-related symptoms in both clinical and non-clinical samples (Longobardi et al., 2017). However, no study has monitored both depression and narcissism in the same sample of competitive and non-competitive BBs, as well as in relation to MD levels. The present study offers new insight about multiple aspects related to $\mathrm{MD}$, including (iv) a significant interaction effect of narcissism/depression levels and group on the levels of MD: only in the $\mathrm{C}-\mathrm{BB}$ group (neither NC-BB or CC) those subjects with higher scores of depression or narcissism showed significantly higher scores of MD.

From these data we could infer alternative conclusions (not mutually excluding). First, (1) there are two possible clusters of BBs (especially among the competing ones) with high MD scores: the first one is characterised by narcissistic traits (and possibly by the prevalence of pride); depressive traits (and perhaps shame) are dominant in the second one. In this way, different developmental trajectories and risk factors can be hypothesised in relation with the two clusters. Secondly, (2) high MD scores in C-BBs and/or NC-BBs could be associated with the prevalence of depressive or narcissistic traits according to the success in maintaining high standard of muscular body image by the subject. According to this view, depressive/narcissistic traits could alternate in the same subject during various stages of life.

In both cases, from a clinical point of view, our data seem to show that two different aetiological paths (or two different phases of the disorder) should be taken in consideration in the possible psychotherapeutic treatment of people with MD.

This approach could be more effective and idiographic in relation to each treated person.

From a theoretic perspective, these observations could enrich and differentiate our present models of priming and maintenance of MD.

\section{Limits of the study and future directions}

Even though our data suggest some novel insight into MD, the study presents some limitations that should be considered in future investigations. First of all, the cross-sectional nature of the study does not allow to infer causality among the different factors. Additionally, MD symptoms were measured with a self-report questionnaire: elevated scores at MDDI might reflect greater risk of displaying MD symptoms, but do not constitute a diagnosis. Our analyses had sometimes limited power as a consequence of low sample size. Finally, pride and shame emotions were not directly evaluated and consequently their possible link to 
narcissism and depression (and MD) is only hypothesised and/or inferred.

Taking into consideration the aforementioned limits, we recommend replication studies with a larger population, using specific instruments to evaluate shame- for example, the Weight- and Body-Related Shame and Guilt Scale (WEB-SG) (Conradt et al., 2007) or the Guilt and Shame Proneness scale (GASP) (Cohen et al., 2011) - and pride for example, the Authentic and Hubristic Pride Scale (Tracy and Robins, 2007).

\section{Compliance with ethical standards}

Ethical approval: all procedures performed in studies involving human participants were in accordance with the ethical standards of the institutional and/or national research committee and with the 1964 Helsinki Declaration and its later amendments or comparable ethical standards.

\section{Conflict of interest}

The authors declare that they have no competing interests.

\section{References}

American Psychiatric Association: Diagnostic and Statistical Manual of Mental Disorders ( $3^{\text {rd }}$ ed.). American Psychiatric Association, Washington, DC 1980.

American Psychiatric Association: Diagnostic and Statistical Manual of Mental Disorders (Fifth Edition). American Psychiatric Association, Washington, DC 2013.

Back MD, Schmukle SC, Egloff B: Why are narcissists so charming at first sight? Decoding the narcissism-popularity link at zero acquaintance. J Pers Soc Psychol 2010; 98: 132-145.

Badenes-Ribera L, Rubio-Aparicio M, Sánchez-Meca J et al.: The association between muscle dysmorphia and eating disorder symptomatology: a systematic review and meta-analysis. J Behav Addict 2019, 8: 351-371.

Beck AT, Steer RA, Brown GK: Beck Depression Inventory - Second Edition Manual. The Psychological Corporation, Harcourt Brace and Company, San Antonio, TX 1996.

Boyda D, Shevlin M: Childhood victimisation as a predictor of muscle dysmorphia in adult male bodybuilders. Ir J Psychol 2011; 32: 105-115.

Bruch H: Eating Disorders: Obesity, Anorexia Nervosa and the Person Within. Basic Books, New York 1973.

Carroll L: A comparative study of narcissism, gender, and sex-role orientation among bodybuilders, athletes, and psychology students. Psychol Rep 1989; 64: 999-1006.

Chandler CG, Grieve FG, Derryberry WP et al.: Are anxiety and obsessive-compulsive symptoms related to muscle dysmorphia? Int J Mens Health 2009; 8: 143-154.

Chung B: Muscle dysmorphia: a critical review of the proposed criteria. Perspect Biol Med 2001; 44: 565-574.

Cohen J: Statistical Power Analysis for the Behavioral Sciences. $2^{\text {nd }}$ ed., Lawrence Erlbaum Associates, Hillsdale, NJ 1988.

Cohen TR, Wolf ST, Panter AT et al.: Introducing the GASP scale: a new measure of guilt and shame proneness. J Pers Soc Psychol 2011; 100: 947-966.

Conradt M, Dierk JM, Schlumberger P et al.: Development of the Weight- and Body-Related Shame and Guilt Scale (WEB-SG) in a nonclinical sample of obese individuals. J Pers Assess 2007; 88: 317-327.

Davis C, Scott-Robertson L: A psychological comparison of females with anorexia nervosa and competitive male bodybuilders: body shape ideals in the extreme. Eat Behav 2000; 1: 33-46.
Dickinson KA, Pincus AL: Interpersonal analysis of grandiose and vulnerable narcissism. J Pers Disord 2003, 17: 188-207.

Ding XF, Gao J, Zhang ZX et al.: Mediation role of shame-focused coping between shame and depression in high school students. Chin Ment Health J 2012; 26: 450-454.

Dozois DJA, Dobson KS, Ahnberg JL: A psychometric evaluation of the Beck Depression Inventory-II. Psychol Assess 1998; 10: 83-89.

Elman WF, McKelvie SJ: Narcissism in football players: stereotype or reality. Athletic Insight 2003; 5: 38-46.

Evans MA: Unattainable beauty: an analysis of the role of body shame and self-objectification in hopelessness depression among collegeage women. Dissertation Abstracts International: Section B: The Science and Engineering 2011; 72 (issue 2-B): 1163.

Fabris MA, Badenes-Ribera L, Longobardi C et al.: Homophobic bullying victimization and muscle dysmorphic concerns in men having sex with men: the mediating role of paranoid ideation. Curr Psychol 2020a. In press.

Fabris MA, Badenes-Ribera L, Longobardi C et al.: Prevalence and cooccurrence of different types of body dysmorphic disorder among men having sex with men. J Homosex 2020b. Accepted for publication.

Fabris MA, Longobardi C, Prino LE et al.: Attachment style and risk of muscle dysmorphia in a sample of male bodybuilders. Psychol Men Masc 2018; 19: 273-281.

Fossati A, Borroni S, Maffei C: Proprietà psicometriche della versione italiana del Narcissistic Personality Inventory. Rivista di Psicologia Clinica 2008; 3: 96-115.

Garner DM, Olmstead MP, Polivy J: Development and validation of a multidimensional Eating Disorder Inventory for anorexia nervosa and bulimia. Int J Eat Disord 1983; 2: 15-34.

Gat I, McWhirter BT: Personality characteristics of competitive and recreational cyclists. J Sport Behav 1998; 21: 408-420.

Ghisi M, Flebus GB, Montano A et al.: Beck Depression Inventory-second edition. Italian adaptation manual. Giunti OS, Florence 2006.

Gilbert P, Miles J (eds.): Body Shame. Conceptualisation, Research and Treatment. Brunner-Routledge, Hove 2002.

Goldfield GS: Body image, disordered eating and anabolic steroid use in female bodybuilders. Eat Disord 2009; 17: 200-210.

Gordon KH, Dombeck JJ: The associations between two facets of narcissism and eating disorder symptoms. Eat Behav 2010; 11: 288-292.

Goss K, Gilbert P: Eating disorders, shame and pride: a cognitivebehavioural functional analysis. In: Gilbert P, Miles J (eds.): Body Shame. Conceptualisation, Research and Treatment. BrunnerRoutledge, Hove 2002: 219-255.

Grabe S, Hyde JS, Lindberg SM: Body objectification and depression in adolescents: the role of gender, shame, and rumination. Psychol Women Q 2007; 31: 164-175.

Grieve FG: A conceptual model of factors contributing to the development of muscle dysmorphia. Eat Disord 2007; 15: 63-80.

Hildebrandt T, Langenbucher J, Schlundt DG: Muscularity concerns among men: development of attitudinal and perceptual measures. Body Image 2004; 1: 169-181.

Hildebrandt T, Schlundt D, Langenbucher J et al.: Presence of muscle dysmorphia symptomology among male weightlifters. Compr Psychiatry 2006; 47: 127-135.

Kuennen MR, Waldron JJ: Relationships between specific personality traits, fat free mass indices, and the Muscle Dysmorphia Inventory. J Sport Behav 2007; 30: 453-470.

Lavender JM, Brown TA, Murray SB: Men, muscles, and eating disorders: an overview of traditional and muscularity-oriented disordered eating. Curr Psychiatry Rep 2017; 19: 32.

Lehoux PM, Steiger H, Jabalpurlawa S: State/trait distinctions in bulimic syndromes. Int J Eat Disord 2000; 27: 36-42.

Littrell CK: Facets of Narcissism in Relation to Muscle Dysmorphia and Eating Disorder Symptomotology. Dissertation Thesis 2015.

Littrell CK, Grieve FG, Derryberry WP et al.: Brief report: relationships among facets of narcissism, symptoms of eating disorders, and symptoms of muscle dysmorphia. J Mens Stud 2020. DOI: $10.1177 / 1060826520918323$.

Longobardi C, Prino LE, Fabris MA et al.: Muscle dysmorphia and psychopathology: findings from an Italian sample of male bodybuilders. Psychiatry Res 2017; 256: 231-236. 
Maida DM, Armstrong SL: The classification of muscle dysmorphia. Int J Mens Health 2005; 4: 73-91.

Mangweth B, Pope HG Jr, Kemmler G et al.: Body image and psychopathology in male bodybuilders. Psychother Psychosom 2001; 70: 38-43.

Matos M, Pinto-Gouveia J, Duarte C: Internalizing early memories of shame and lack of safeness and warmth: The mediating role of shame on depression. Behav Cogn Psychother 2013; 41: 479-493.

Miller KJ, Mesagno C: Personality traits and exercise dependence: Exploring the role of narcissism and perfectionism. Int J Sport Exerc Psychol 2014; 12: 368-381.

Mitchell L, Murray SB, Cobley S et al.: Muscle dysmorphia symptomatology and associated psychological features in bodybuilders and non-bodybuilder resistance trainers: a systematic review and meta-analysis. Sports Med 2017; 47: 233-259.

Murray SB, Griffiths S, Mond JM et al.: Anabolic steroid use and body image psychopathology in men: delineating between appearanceversus performance-driven motivations. Drug Alcohol Depend 2016; 165: 198-202.

Murray SB, Rieger E, Hildebrandt T et al.: A comparison of eating, exercise, shape, and weight related symptomatology in males with muscle dysmorphia and anorexia nervosa. Body Image 2012; 9: 193-200.

Murray SB, Rieger E, Touyz SW et al.: Muscle dysmorphia and the DSM-V conundrum: where does it belong? A review paper. Int J Eat Disord 2010; 43: 483-491.

Olejnik S, Algina J: Generalized eta and omega squared statistics: measures of effect size for some common research designs. Psychol Methods 2003; 8: 434-447.

Olivardia R: Mirror, mirror on the wall, who's the largest of them all? The features and phenomenology of muscle dysmorphia. Harv Rev Psychiatry 2001; 9: 254-259.

Olivardia R, Pope HG Jr, Hudson JI: Muscle dysmorphia in male weightlifters: a case-control study. Am J Psychiatry 2000; 157: 1291-1296.

Phillips KA, Hollander E, Rasmussen SA et al.: A severity rating scale for body dysmorphic disorder: development, reliability, and validity of a modified version of the Yale-Brown Obsessive Compulsive Scale. Psychopharmacol Bull 1997; 33: 17-22.

Phillips KA, Wilhelm S, Koran LM et al.: Body dysmorphic disorder: some key issues for DSM-V. Depress Anxiety 2010; 27: 573-591.

Pincus AL, Lukowitsky MR: Pathological narcissism and narcissistic personality disorder. Annu Rev Clin Psychol 2010; 6: 421-446.

Pope CG, Pope HG, Menard W et al.: Clinical features of muscle dysmorphia among males with body dysmorphic disorder. Body Image 2005; 2: 395-400.

Pope HG Jr, Katz DL: Psychiatric and medical effects of anabolicandrogenic steroid use. A controlled study of 160 athletes. Arch Gen Psychiatry 1994; 51: 375-382.

Pope HG Jr, Gruber AJ, Choi P et al.: Muscle dysmorphia. An underrecognized form of body dysmorphic disorder. Psychosomatics 1997; 38: 548-557.
Pope HG Jr, Katz DL, Hudson JI: Anorexia nervosa and "reverse anorexia” among 108 male bodybuilders. Compr Psychiatry 1993; 34: 406-409.

Porcerelli JH, Sandler BA: Narcissism and empathy in steroid users. Am J Psychiatry 1995; 152: 1672-1674.

Raskin R, Terry H: A principal-components analysis of the Narcissistic Personality Inventory and further evidence of its construct validity. J Pers Soc Psychol 1988; 54: 890-902.

Raskin RN, Hall CS: A narcissistic personality inventory. Psychol Rep 1979; 45: 590

Rohman L: The relationship between anabolic androgenic steroids and muscle dysmorphia: a review. Eat Disord 2009; 17: 187-199.

del Rosario PM, White RM: The Narcissistic Personality Inventory: test-retest stability and internal consistency. Pers Individ Dif 2005; 39: 1075-1081.

Rubinstein G: Macho man: narcissism, homophobia, agency, communion, and authoritarianism - a comparative study among Israeli bodybuilders and a control group. Psychol Men Masc 2003; 4: 100-110.

Rubio-Aparicio M, Badenes-Ribera L, Sánchez-Meca J et al.: A reliability generalization meta-analysis of self-report measures of muscle dysmorphia. Clin Psychol Sci Pract 2020; 27: e12303.

Santarnecchi E, Dèttore D: Muscle dysmorphia in different degrees of bodyboulding activities: validation of the Italian version of Muscle Dysmorphia Disorder Inventory and Bodybuilder Image Grid. Body Image 2012; 9: 396-403.

Schwerin MJ, Corcoran KJ, Fisher L et al.: Social physique anxiety, body esteem, and social anxiety in bodybuilders and self-reported anabolic steroid users. Addict Behav 1996; 21: 1-8.

Settanni M, Prino LE, Fabris MA et al.: Muscle dysmorphia and anabolic steroid abuse: can we trust the data of online research? Psychiatry Res 2018; 263: 288.

Skemp KM, Mikat RP, Schenck KP et al.: Muscle dysmorphia: risk may be influenced by goals of the weightlifter. J Strength Cond Res 2013; 27: 2427-2432.

Steinberg BE, Shaw RJ: Bulimia as a disturbance of narcissism: selfesteem and the capacity to self-soothe. Addict Behav 1997; 22: 699-710.

Thompson A, Kent G: Adjusting to disfigurement: processes involved in dealing with being visibly different. Clin Psychol Rev 2001; 21 : 663-682.

Tracy JL, Robins RW: The psychological structure of pride: a tale of two facets. J Pers Soc Psychol 2007; 92: 506-525.

Walberg JL, Johnston CS: Menstrual function and eating behavior in female recreational weight lifters and competitive body builders. Med Sci Sports Exerc 1991; 23: 30-36. 